JURNAL ILMIAH KEBIDANAN IMELDA

Vol.6, No.1, Maret 2020, pp. 26-31

ISSN: 2597-7180 (Online), 2442-8116 (Print)

\title{
PENGARUH MEDIA AUDIO VISUAL TERHADAP TINGKAT PENGETAHUAN DAN SIKAP PADA IBU HAMIL TENTANG PENCEGAHAN STUNTING DI DESA CINTA RAKYAT
}

\author{
Sopyah Anggraini ${ }^{1}$, Sarmaida Siregar ${ }^{2}$, Ratna Dewi ${ }^{3}$ \\ Universitas Imelda Medan, Indonesia
}

\section{Article Info}

\section{Keywords:}

Knowledge

Attitude

Pregnant Women

Prevention of Stunting

Audio Visual Media

\begin{abstract}
Stunting or chronic malnutrition is another form of growth failure, and chronic malnutrition. Stunting can also occur before birth and is caused by poor nutritional intake during pregnancy, (Unicef Indonesia, 2012). Stunting is influenced by family income factors, maternal nutritional knowledge, parenting, history of disease infection, history of immunization, protein intake, and maternal intake. Maternal intake, especially during pregnancy is one of the factors that play an important role. Fetal nutrition depends entirely on the mother, so that the adequacy of maternal nutrition greatly affects the condition of the fetus it contains. Pregnant women who are malnourished or lack of food intake will cause fetal growth disorders in the womb (Picauly, 2013). In terms of reducing the incidence of stunting in pregnant women can be done through promotion and prevention. One such effort is to conduct health education using the media. The media provides information and education that aims to increase knowledge and foster a positive attitude towards stunting prevention. This is one of the main reasons for researchers to find out the effect of audio-visual media on the knowledge and attitudes of pregnant women about stunting prevention in Cinta Rakyat Village. This type of research is quantitative conducted in Cinta Rakyat Village and aims to determine the effect of audio-visual media on knowledge and attitudes towards pregnant women about stunting prevention in Cinta Rakyat Village. Sampling using probability sampling technique type of purposive sampling that met the inclusion criteria as many as 42 people. The results showed that pregnant women had a significant difference between the knowledge and attitudes of pregnant women before and after the intervention using audio visual media with a $p$ value of $0.001(p<0.05)$. The results of this study are expected for pregnant women in Cinta Rakyat Village to increase knowledge and attitudes as well as information so as to prevent stunting in babies born.
\end{abstract}

This is an open access article under the CC BY-SAlicense.

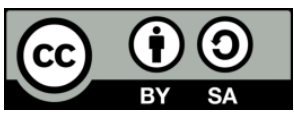

\section{Corresponding Author:}

Sopyah Anggraini,

Program Studi D-III Keperawatan,

Universitas Imelda Medan,

Jl. Bilal No. 52 Kelurahan Pulo Brayan Darat I Kecamatan Medan Timur, Medan - Sumatera Utara.

Email: sopyahanggraini08@gmail.com 


\section{INTRODUCTION}

Stunting atau kurang gizi kronik adalah suatu bentuk lain dari kegagalan pertumbuhan, dan kurang gizi kronik. Keadaan yang sudah terjadi sejak lama, bukan seperti kurang gizi akut. Stunting dapat juga terjadi sebelum kelahiran dan disebabkan oleh asupan gizi yang sangat kurang saat masa kehamilan, pola asuh makan yang sangat kurang, rendahnya kualitas makanan sejalan dengan frekuensi infeksi sehingga dapat menghambat pertumbuhan (Unicef Indonesia, 2012).

Stunting adalah masalah kurang gizi kronis yang disebabkan oleh kurangnya asupan gizi dalam waktu yang cukup lama, sehingga mengakibatkan gangguan pertumbuhan pada anak yakni tinggi badan anak lebih rendah atau pendek (kerdil) dari standar usianya (Kemenkes, 2018).

Data WHO (2014) mencatat sekitar seperempat atau 24,5\% anak balita di dunia mengalami stunting. Sekitar $80 \%$ anak stunting di dunia tinggal di 14 negara. 183 Prevalensi stunting terbesar di dunia yaitu di India dengan prevalensi stunting 48\% (61.723 jumlah anak stunting), prevalensi terbesar kedua yaitu Nigeria, Pakistan, China dan Indonesia adalah negara dengan prevalensi stunting kelima terbesar dengan prevalensi $36 \%$ (7.547 jumlah anak stunting) (Unicef, 2013).

Berdasarkan data Riskesdas (2013) prevalensi anak balita stunting di Indonesia pada tahun 2007 sebesar 36,8\%, pada tahun 2010 terjadi penurunan sebesar 35,5\% dan pada tahun 2013 terjadi peningkatan menjadi 37,2\%. Berdasarkan hasil PSG Kemenkes (2015) provinsi Nusa Tenggara Timur adalah prevalensi stunting tertinggi di Indonesia sebesar 41,2\%, sedangkan prevalensi stunting di Jawa Barat sebesar 25,6\%.

Hasil penelitian menunjukkan bahwa stunting dipengaruhi oleh faktor pendapatan keluarga, pengetahuan gizi ibu, pola asuh ibu, riwayat infeksi penyakit, riwayat imunisasi, asupan protein, dan asupan ibu. Asupan ibu terutama saat hamil merupakan salah satu faktor yang berperan penting. Gizi janin bergantung sepenuhnya pada ibu, sehingga kecukupan gizi ibu sangat memengaruhi kondisi janin yang dikandungnya. Ibu hamil yang kurang gizi atau asupan makanan kurang akan menyebabkan gangguan pertumbuhan janin dalam kandungan (Picauly, 2013).

Kurangnya kesadaran tentang pentingnya gizi ibu akan berdampak pada kurangnya upaya yang dilakukan untuk pencegahan stunting. Kondisi ini tentunya akan berlanjut sampai dengan anak lahir dan tumbuh. Dalam perkembangannya, anak yang bertubuh pendek dianggap wajar dan tidak berdampak untuk perkembangan anak selanjutnya sehingga tidak memerlukan penanganan khusus.

Seiring dengan perkembangan zaman, media audio visual sangat memungkinkan sebagai media dalam meningkatkan pengetahuan, yaitu dengan menggunakan video. Video merupakan media audio-visual yang dapat mengungkapkan objek dan peristiwa seperti keadaan sesungguhnya, dengan menggunakan video seseorang mampu memahami pesan pembelajaran secara lebih bermakna sehingga informasi yang disampaikan melalui video tersebut dapat dipahami secara utuh (Setiawati, 2008).

Penggunaan media cetak/ visual yang dihasilkan melalui proses mekanik dan fotografis hanya menstimulasi indra mata (penglihatan), sedangkan media audio visual dihasilkan melalui proses mekanik dan elektronik dengan menyampaikan pesan atau informasi secara audio dan visual memberikan stimulus terhadap mata (penglihatan) dan telinga (pendengaran) (Setiawati, 2008).

Penelitian Nurhayati et al (2016), Perbedaan promosi kesehatan dengan leaflet dan audio visual terhadap Pengetahuan dan Sikap tentang pencegahan stunting pada Ibu hamil menujukkan bahwa media audio visual lebih meningkatkan pengetahuan Ibu dibanding leaflet. Ibu hamil sebagai target sasaran penyuluhan pendidikan kesehatan tentang Pencegahan stunting, didasari pada asumsi bahwa secara psikologis karakteristik kepribadian Ibu hamil bersifat labil.

Berdasarkan survey awal yang penulis lakukan dengan mengadakan wawancara langsung kepada 15 Ibu hamil di Desa Cinta Rakyat, penulis mendapatkan informasi bahwa Ibu hamil tersebut mengetahui tentang pencegahan terjadinya stunting dan diantara mereka mempunyai Pengetahuan stunting sangat terbatas, hanya sekedar tahu bahwa stunting berbahaya, tidak memiliki pengetahuan yang luas tentang pencegahan stunting, berdasarkan pernyataan dari pihak desa selama lima tahun terakhir ini belum ada penyuluhan tentang pencegahan stunting di desa tersebut, sejalan dengan pendapat pihak desa beberapa Ibu juga mengatakan belum pernah mendapat pendidikan kesehatan dengan media audiovisual, menurut pendapat mereka pendidikan kesehatan dengan media audio visual sangat menarik karena umumnya pendidikan kesehatan dengan metode ceramah yang mengakibatkan cepat bosan dan monoton.

Penelitian lain yang berjudul Tingkat Pengetahuan Ibu Tentang Pentingnya Gizi Untuk Tumbuh Kembang Bayi Di Klinik Aditya Helvetia Medan Tahun 2016 menyatakan bahwa tingkat pengetahuan ibu tentang pentingnya gizi untuk tumbuh kembang bayi masih kurang (Sinaga, 2017). Melihat fenomena diatas, maka perlu diberikan tambahan informasi untuk meningkatkan pengetahuan dan sikap Ibu hamil tentang pencegahan stunting. Berdasarkan penjelasan diatas, penulis tertarik untuk melakukan penelitian dengan judul "Pengaruh media audiovisual terhadap tingkat pengetahuan dan sikap Ibu hamil tentang pencegahan stunting di Desa Cinta Rakyat". 
Berdasarkan latar belakang yang telah dikemukakan, maka yang menjadi rumusan masalah dalam penelitian ini adalah bagaimana pengaruh media audio visual terhadap pengetahuan dan sikap ibu hamil tentang pencegahan stunting di Desa Cinta Rakyat.

\section{RESEARCH METHOD}

Metode kuantitatif, dengan desain penelitian menggunakan metode kuasi eksperimen (Quasi Experiment), dengan rancangan penelitian yang digunakan adalah rancangan pre-test and post-test group design. Penelitian dilakukan pada bulan Januari sampai Februari 2020. Penelitan dilakukan di Desa Cinta Rakyat. Populasi pada penelitian ini adalah semua Ibu hamil yang ada di Desa Cinta Rakyat. Tekhnik pengambilan Sampel: Probability Sampling dengan metode Purposive Sampling. Besar Sampel 42 orang.

\section{RESULTS AND ANALYSIS Karakteristik Responden}

Tabel 1. Distribusi Karakteristik Ibu Hamil di Desa Cinta Rakyat 2020 (n= 42)

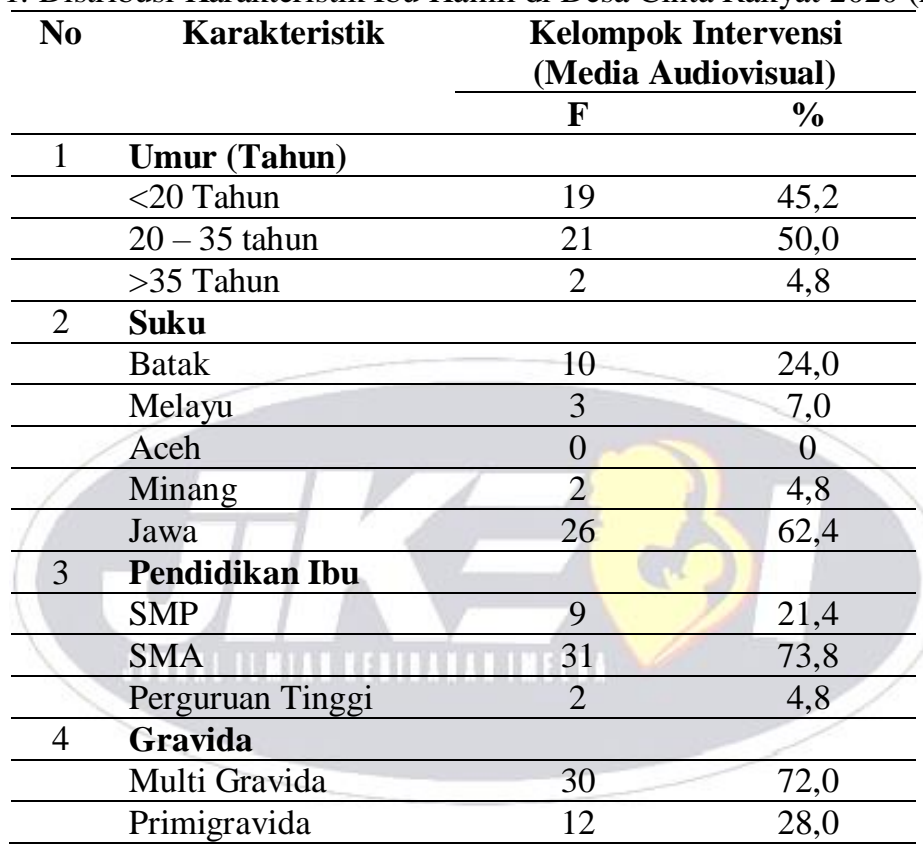

Berdasarkan tabel diketahui bahwa subjek penelitian paling banyak berumur 20-35 tahun, yaitu $50,0 \%$, suku paling banyak suku jawa, yaitu 62,4\%, tingkat pendidikan ibu paling banyak pendidikan SMA sebesar 73,8\%, sebagian besar pekerjaan ibu adalah ibu rumah tangga 94,2\% dan ibu yang memiliki anak lebih dari 1 orang (multigravida) sebanyak $72,0 \%$.

Tabel 2. Distribusi Frekuensi Ibu Hamil Berdasarkan Skor Pengetahuan Sebelum Intervensi Dengan Media Audio Visual

\begin{tabular}{lcc}
\hline Kategori & \multicolumn{2}{c}{ Intervensi (Media Audio Visual) } \\
\cline { 2 - 3 } Pengetahuan & F & \% \\
\hline Baik & 13 & 31,0 \\
\hline Cukup & 20 & 47,6 \\
\hline Kurang & 9 & 21,4 \\
\hline \multicolumn{1}{c}{ Total } & $\mathbf{4 2}$ & $\mathbf{1 0 0}$
\end{tabular}

Berdasarkan tabel menunjukkan bahwa dari 42 Ibu hamil berdasarkan kategori pengetahuan sebelum dengan intervensi media audio visual mayoritas berpengetahuan cukup sebanyak 20 orang $(47,6 \%)$. 
Tabel 3. Distribusi Frekuensi Ibu Hamil Berdasarkan Skor Sikap Sebelum Intervensi Dengan Media Audio Visual

\begin{tabular}{lcc}
\hline \multirow{2}{*}{ Kategori Sikap } & \multicolumn{2}{c}{ Intervensi (Media Audio Visual) } \\
\cline { 2 - 3 } & $\mathbf{F}$ & $\mathbf{\%}$ \\
\hline Baik & 7 & 16,7 \\
\hline Cukup & 25 & 59,9 \\
\hline Kurang & 10 & 23,8 \\
\hline Total & $\mathbf{4 2}$ & $\mathbf{1 0 0}$ \\
\hline
\end{tabular}

Berdasarkan tebel menunjukkan bahwa dari 42 Ibu hamil berdasarkan kategori sikap sebelum intervensi dengan media audio visual mayoritas bersikap cukup sebanyak 25 orang $(59,9 \%)$.

Tabel 4. Distribusi Frekuensi Ibu Hamil Berdasarkan Skor Pengetahuan Setelah Intervensi Dengan Media Audio Visual

\begin{tabular}{lcc}
\hline \multirow{2}{*}{ Kategori Pengetahuan } & Intervensi (Media Audio Visual) \\
\cline { 2 - 3 } & $\mathbf{F}$ & $\mathbf{\%}$ \\
\hline Baik & 40 & 95,20 \\
\hline Cukup & 2 & 4,80 \\
\hline Kurang & 0 & 0 \\
\hline \multicolumn{1}{c}{ Total } & $\mathbf{4 2}$ & $\mathbf{1 0 0}$
\end{tabular}

Berdasarkan tabel menunjukkan bahwa dari 42 Ibu hamil berdasarkan kategori pengetahuan setelah dengan intervensi media audio visual mayoritas berpengatahuan baik sebanyak 40 orang (95,20\%).

Tabel 5. Distribusi Frekuensi Ibu Hamil Berdasarkan Skor Sikap Setelah Intervensi Dengan Media Audio Visual

\begin{tabular}{lcc}
\hline \multirow{2}{*}{ Kategori } & \multicolumn{2}{c}{ Intervensi (Media Audio Visual) } \\
\cline { 2 - 3 } Sikap & $\mathbf{F}$ & $\mathbf{\%}$ \\
\hline Baik & 40 & 95,20 \\
\hline Cukup & 2 & 4,80 \\
\hline Kurang & 0 & 0 \\
\hline \multicolumn{1}{c}{ Total } & $\mathbf{4 2}$ & $\mathbf{1 0 0}$ \\
\hline
\end{tabular}

Berdasarkan tabel menunjukkan bahwa dari 42 Ibu hamil berdasarkan kategori sikap setelah dengan intervensi media audio visual mayoritas bersikap baik sebanyak 40 orang $(95,20 \%)$.

Tabel 6. Distribusi Beda Rerata Selisih Skor Pengetahuan dan Sikap Ibu hamil tentang Pencegahan Stunting Sebelum dan Setelah Intervensi Dengan Media Audio Visual

\begin{tabular}{|c|c|c|c|c|c|c|}
\hline \multirow[t]{2}{*}{ Variabel } & \multicolumn{2}{|c|}{ Sebelum } & \multicolumn{2}{|c|}{ Setelah } & \multirow{2}{*}{$\begin{array}{c}\text { Mean } \\
\text { Difference }\end{array}$} & \multirow[t]{2}{*}{ P Value } \\
\hline & Mean & SD & Mean & SD & & \\
\hline Pengetahuan & 33,83 & 8,151 & 37,64 & 6,488 & 3,810 & 0,001 \\
\hline Sikap & 43,52 & 7,306 & 47,45 & 8,937 & 3,930 & 0,004 \\
\hline
\end{tabular}

Berdasarkan tabel ada perbedaan yang signifikan antara pengetahuan Ibu hamil sebelum dan sesudah intervensi menggunakan media audio visual dengan $p$ value $0,001(p<0,05)$ dan ada perbedaan yang signifikan antara sikap Ibu hamil sebelum dan sesudah intervensi menggunakan media audio visual dengan $p$ value $0,004(p<0,05)$.

Sesuai dengan hasil penelitian Nurhayati, Vivin, dan Kurnia (2013), menunjukkan adanya peningkatan pengetahuan Ibu. Jenis media ini mempunyai kemampuan yang lebih baik, karena meliputi kedua jenis media auditif (mendengar) dan visual (melihat) yang berarti bahan atau alat yang dipergunakan dalam situasi belajar untuk membantu tulisan dan kata yang diucapkan dalam menularkan pengetahuan, sikap, dan ide.

Penelitian ini didukung oleh Sarmaida (2018) dimana penggunaan media audio visual dapat meningkatkan pengetahuan dan sikap remaja tentang bahaya merokok. Penelitian Ode (2014), dimana penggunaan media audio visual berpengaruh terhadap pengetahuan siswa SMP di Makurdi mengalami peningkatan atas apa yang telah diketahui dari pesan kesehatan 


\section{CONCLUSION}

Berdasarkan hasil penelitian serta pembahasan yang disertai dengan teori dan hasil penelitian lain yang mendukung mengenai Variasi Perubahan Berat Badan Akseptor KB Implan, Suntik dan pil diwilayah Kerja Puskesmas Terjun Kecamatan Medan Tembung, maka diperoleh kesimpulan adanya peningkatan berat badan pada akseptor KB impaln, suntik dan pil.

\section{REFERENCES}

Arikunto, S. (2010). Prosedur Penelitian Suatu Pendekatan Praktik. Jakarta: Rineka Cipta.

Arum, D. N. S., \& Sujiyatini (2014). Panduan lengkap pelayanan KB terkini. Yogyakarta: Nuha Medika.

BKKBN, (2013). Laporan umpan balik pelayanan kontrasepsi. http://aplikasi.bkkbn.go.id/sr, diperoleh tanggal 22 Oktober 2016.

Budiyanto, (2012). Mencegah kekanaikan berat badan akibat KB hormnal. http://blogspot.co.id/2014/11/mencegah-kegemukan-yang-disebabkan-oleh-hormon.html, diperoleh tanggal 03 Juni 2017.

Cipto Surono, (2000). Pengertian Berat Badan. https://pengertianberatbadan.wordpress.com/ diperoleh tanggal 19 oktober 2016.

Ganong, (2003). Hubungan antara hormon dan berat badan http://ehormon.blogspot.co.id/2014/11/hubungan-antara-hormon-dan-berat-badan.html, diperoleh tanggal 03 Juni 2017.

Hartanto, (2003), pengertian Akseptor KB. http://wawanjokamblog.blogspot.co.id/2009/07/akseptor-kb.html, diperoleh tanggal 22 Oktober 2016.

Hastono. P. S. , Sabri. L., (2010) Statistik Kesehatan Jakarta : PT Raja Grafindo Persada.

Hutauruk, P. M. (2019). FAKTOR - FAKTOR YANG MEMPENGARUHI RENDAHNYA PENGETAHUAN IBU UNTUK MEMILIH IMPLANT SEBAGAI ALAT KONTRASEPSI DI KELURAHAN TERJUN KECAMATAN MEDAN MARELAN TAHUN 2018. Jurnal Ilmiah Kebidanan Imelda, 5(1), 606-611.

Manuaba. I. A. C. , ((2009). Memahami kesehatan reproduksi wanita.Edis 2 : Jakarta : ECG.

Notoatmodjo.S., (2010). Metodologi penelitian kesehatan Jakarta : Rineka Cipta

Nugroho.T. \& Utama. I. B. Dr., (2014). Masalah kesehatan reproduksi wanita. Yogyakarta : Nuha Medika.

Kepmenkes RI, (2013), Situasi keluarga berencana di Indonesia. http//buletin-kespro.pdf. diperoleh tanggal 23 Oktober 2013.

Sibagariang, E., Pusmaika R., \& Rismalinda, (2010). Kesehatan Reproduksi wanita. Jakarta Timur : CV. Trans Info Media.

Siregar, E. (2009) Hubungan Antara penggunaan alat kotrasepsi suntik 3 bulan dengan Pertambhan berat badan akseptor KB. Jurnal kebidanan haga, 2(4) Juni, 4-5.

Soetjiningsih, (1995), Pengertian Berat Badan.https://pengertianberatbadan.wordpress.com/di diperoleh 19 Oktober 2016.

Suparyanto, dr. (2010), Pengertian berat badan http://dr-suparyanto.blogspot.co.id/2010/12/pengaruh-kbsuntik-terhadap-perubahan.html, diproleh tanggal 22 Oktober 2016.

Surono C., 2009, pengertian berat badan. https://pengertianberatbadan.wordpress.com/diakses tanggal 19 oktober 2016.

Udin S. Winataputra, (2004), Pengertian Variasi. http://ghufron-dimyati.blogspot.co.id, diperoleh tanggal 05 November 2016

Yanti, (2014) Buku ajar kesehatan reproduksi untuk mahasiswi kebidanan. Yogyakarta: Pustaka Rihama. 


\section{BIOGRAPHIES OF AUTHORS}

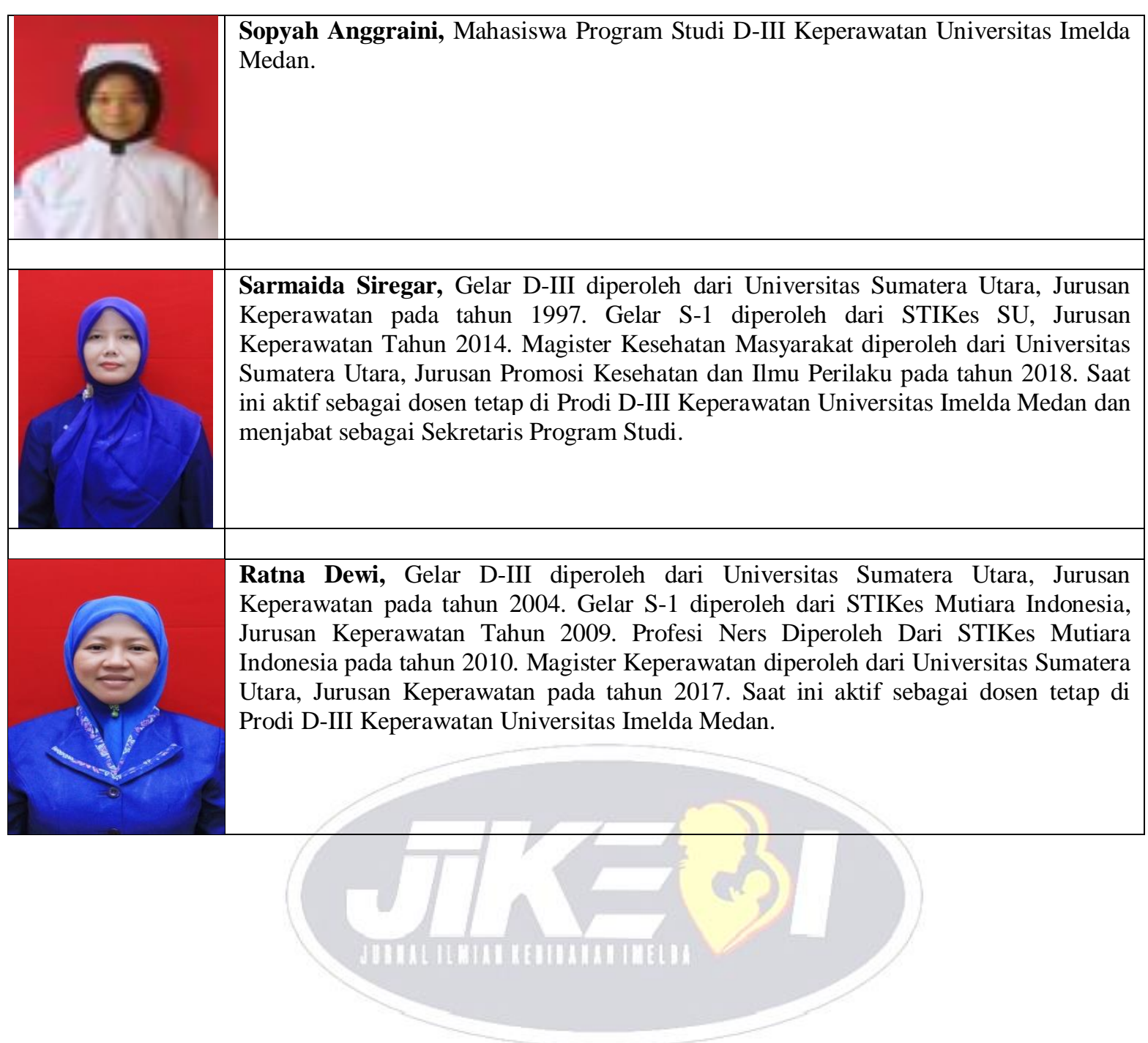

